\title{
-Cell Disease
}

National Cancer Institute

\section{Source}

National Cancer Institute. I-Cell Disease. NCI Thesaurus. Code C61270.

An inherited lysosomal storage disease characterized by the presence of dense intracytoplasmic inclusions in mesenchymal cells, especially fibroblasts. Signs and symptoms include developmental delay, psychomotor deterioration, and growth failure. 